\title{
Christiane Deloince-Louette, Sponde, Homère et Du
} Bartas

\section{Filippo Fassina}

\section{OpenEdition \\ Journals}

\section{Edizione digitale}

URL: http://journals.openedition.org/studifrancesi/5589

DOI: 10.4000/studifrancesi.5589

ISSN: 2421-5856

\section{Editore}

Rosenberg \& Sellier

\section{Edizione cartacea}

Data di pubblicazione: 1 septembre 2011

Paginazione: 398-399

ISSN: 0039-2944

\section{Notizia bibliografica digitale}

Filippo Fassina, «Christiane Deloince-Louette, Sponde, Homère et Du Bartas», Studi Francesi [Online], 164 (LV | II) | 2011, online dal 30 novembre 2015, consultato il 13 janvier 2021. URL: http://

journals.openedition.org/studifrancesi/5589; DOI: https://doi.org/10.4000/studifrancesi.5589

Questo documento è stato generato automaticamente il 13 janvier 2021.

\section{@(๑) $\Theta \Theta$}

Studi Francesi è distribuita con Licenza Creative Commons Attribuzione - Non commerciale - Non opere derivate 4.0 Internazionale. 


\title{
Christiane Deloince-Louette, Sponde, Homère et Du Bartas
}

\author{
Filippo Fassina
}

\section{NOTIZIA}

CHRISTIANE DELOINCE-LOUETTE, Sponde, Homère et Du Bartas, «Bibliothèque d'Humanisme et Renaissance», LXXI, 2 (2009), pp. 255-270.

1 Nel presente contributo viene analizzato il rapporto fra Jean de Sponde e Guillaume de Saluste du Bartas, che probabilmente si conobbero alla corte di Nérac attorno all'anno 1578. Dal punto di vista letterario, l'A. esamina due passi di un'opera di Sponde (il commento ai testi omerici uscito a Bâle nel 1583) nella quale viene citata la Sepmaine di Du Bartas, dimostrando così il debito di un autore nei confronti dell'altro e la grande circolazione del testo di Du Bartas. I passi del commento all'Iliade di Sponde che vengono presi in considerazione sono la descrizione dello scudo di Achille (libro XVIII) e l'intero libro IX. In particolare, Sponde riprende la celebre critica che Du Bartas muove alla "frénétique France», travolta dalle guerre intestine, e utilizza tale espressione per giudicare la guerra di Troia, dimostrando la volontà di dare, attraverso la citazione della Sepmaine, una lettura etica del poema omerico. 